\title{
Sætningsled, kasus og signifikation
}

\author{
HANS GÖTZSCHE \\ Institut for Kommunikation, Aalborg Universitet, Danmark
}

\begin{abstract}
In this presentation I try to conceive of the theme of the colloquium as a problem concerning semantic or thematic roles. I find it hard to support an idea about these roles as being semantic entities and/or explaining tools in grammar. My basis for this is a certain linguistic theory, Formative Grammar, developed by me, and implying that the linguistic functions of human beings have a specific architecture. The theory is both formal, including formalisms, and incorporated in a pragmatic framework, a theory of universal pragmatics.
\end{abstract}

It follows from this that the way in which sentences are often regarded as mirrors of roles acting in scenarios, is inadequate. Not all, if even most, of the situations we encounter can be depicted by means of role theories since fairly large parts of nature is inhabited by nonhuman entities, and sentences have to deal with these too. Another objection deals the philosophical basis that claims about role theory. My main concern is they cannot be defined in a satisfactory way as entities and that one is not able to set up criteria for the falsification of the claims mentioned.

As for sentences constituents I see them as expressions of concepts, and I see grammatical case as one way of telling the language users what syntactic status a specific constituent has. Case is a part of what I call morphological signification (another part is verbal conjugation), and this is opposed to what I call topological signification, i.e. the syntactic categories are revealed by the linear distribution of the constituents. Roles play no part in this model of syntactic functions.

\section{Problemet}

Dette er jo en bunden opgave: Kollokviets tema er "Kasus, sætningsled og semantiske roller", og man sammensætter vel et tema fordi man mener at der er en eller anden forbindelse mellem de indgående begreber. De tre her nævnte Tidsskrift for Sprogforskning • Årgang 4 • Nr. 1-2 • 2006, pp. 39-54 
består måske af lidt sammenbragte ord: 'kasus' går tilbage til latinen, 'sætningsled' er i snæver forstand et ikke helt nyt dansk fænomen men findes også i en lidt anden aftapning i det tyske 'Satzglied(er)', mens 'semantik' er en fransk 1800-talsopfindelse. 'Rollerne' har til gengæld vundet indpas og udbredelse i moderne lingvistik, og i en løbende opdateret elementær lærebog i semantik som Saeed (2003) får de et helt kapitel for sig under betegnelsen "thematic roles" (Saeed 2003: 148-180). Hos Fillmore, som nævnes på s. 148 er de koblet til hvad han som bekendt kalder "deep semantic cases", hvilket evt. kan retfærdiggøre at man sætter dem i mulig forbindelse med grammatisk kasus. Som det vil være de fleste bekendt - det er så at sige en præsupposition i medfør af ovennævnte tema - så antager man at der findes en række kategorier som fx 'agent', 'patient', 'instrument', 'mål' og 'kilde' (oversat frit fra Saeed 2003: 149150) som kaldes semantiske og som antages at kunne forklare visse træk ved det sproglige udtryk. Således kan 'agenten' sommetider kobles til et grammatisk subjekt som i nogle tilfælde står i nominativ, men sammenfaldet mellem semantiske og syntaktisk-morfologiske kategorier er ikke udpræget entydigt, hvilket bl.a. medfører at forskellige rolleteoretikere har hver deres liste over semantiske roller. Lidt ligesom at enhver dansk grammatiker med respekt for sig selv helst skal lave sin egen version af Diderichsens sætningsskema. Der er nu to problemer i forbindelse med det her: det ene drejer sig om det grundlæggende teoretiske spørgsmål hvorvidt det kan retfærdiggøres empirisk at der teoretisk antages at være størrelser som 'semantiske roller', mens det andet drejer sig om det lidt mere inferiøre spørgsmål hvorfra folk har deres idé om eksistensen af 'rollerne' samt hvorfor folk har dem - idéerne altså. Jeg vil forsøge at besvare begge spørgsmål i sammenhæng med at jeg afskaffer de pågældende roller.

\section{HVAD ER SPROG?}

Det er jo et godt spørgsmål, men en enkelt ting bør klargøres først. Der er elementær forskel på, på den ene side, at observere noget og derefter beskrive det, og på den anden side at opstille teorier om hvad der ikke kan observeres spontant eller ved hjælp af instrumenter. Mit yndlingseksempel er det fonetiske træk (feature) 'stemthed' som enten kan høres eller identificeres ved hjælp af apparater, og som derefter kan indgå i en fonologisk model. I modsætning hertil er det noget sværere at lave en 'feature'-beskrivelse af fx semantiske forhold, og en sådan forudsætter at man har præsenteret en anvendelig teoretisk definition 
af hvad en 'feature' er for noget, og man bør være klar over at 'feature' i så fald kun er et teoretisk begreb og ikke en betegnelse på et observerbart fænomen, og at ens teori kan blive udkonkurreret af andre teorier som evt. ikke behøver bruge begrebet 'feature'. Folk som Hjelmslev og Chomsky gør det ikke altid klart at (eller om?) de selv skelner tydeligt mellem observation og teori, og når jeg således skal svare på spørgsmålet "hvad er sprog" bliver jeg nødt til at erkende at jeg må have en sprogteori, for tilsyneladende kan alle de fænomener som betegnes som sprog ikke beskrives og forklares fyldestgørende uden at der opstilles nogle begreber om det der ikke kan observeres og som i bred forstand kan kaldes strukturer. Den teori som jeg er kommet frem til kalder jeg 'Formative Grammar' og den medfører følgende model af det sproglige tegn: 
The linguistic sign

linguistic material structures (media): sounds and writings

।

MEDIUM ASSIGNMENT: the mental and material processes of producing

(creating or utilizing) articulation and writing

।

mental images from perception (representations) and cognition

(discourse: structures: constructions:

utterance language sign minimal sign)

expression(s) form (gramma-*) style sentence (of constituents)

|**

$\operatorname{exposition}(\mathrm{s}) \quad$ sense $\left(\right.$ sema $\left.^{*}\right) \quad$ logic statement (of concepts)

|**

content(s) meaning (pragma- ${ }^{*}$ information stratification (of

configurations)

mental images from perception (representations) and cognition

।

OBJECT ASSIGNMENT: the processes of activating (creating or actualizing) one or more concepts (of mental objects or (as mental representations of) material objects) - so that they are part of the conscious mental universe - connected (as reference) with related interactions with the world

।

material structures: the world

** mental structures of SIGNIFICATION

* structures

* 1 processes of cognition (processing mental objects) and perception (processing the relation between mental objects (as mental representations of material objects) and material objects)

*2 interaction with other human beings and/or nature (manipulating material objects)

*3 reference: object assignment of a material object (a number of related objects) 
This model distinguishes between mental and material entities and properties; this is another distinction than the one between, on the one hand, physical entities, properties etc. (those within the limits of possible knowledge) and, on the other hand, non-physical entities, properties etc. (those beyond the limits of possible knowledge (metaphysics is something else, i.e. basic assumptions about physics)); accordingly both mental and material entities and properties are considered physical. A more detailed account of this model of the linguistics sign - and the original model displayed in the 1st and 2nd edition of the my Doctoral Thesis (Götzsche 1994) - is offered in Götzsche (2005a).

Det her er så at sige Saussures burger-model (jf. de Saussure 1919: 99) udvidet til en dansk lagkage. Saussure antager to størrelser: udtryk og indhold, mens jeg antager tre lag: udtryk, indhold og - hvad jeg på dansk ville kalde - fremsættelse. Modellen kan selvsagt ikke stå alene; den må underbygges af et større formuleret teoriapparat, og det kan man finde i mine øvrige udgivelser. Indtil videre ved vi uendeligt lidt om hvad der foregår i hjernen og derfor må vi nøjes med teorier og modeller af hvad vi kan kalde et kognitivt system eller et mentalt-konceptuelt system, og så lade forklaringskraften afgøre hvilke der formodentlig er mest sande. Men det er ikke altid let at mobilisere den fornødne afbalancerede holdning. På et tidspunkt skrev jeg til Martin Haspelmath at

[b]y accident, I read the article "Fahndung im Buchstabensalat" in Der Spiegel 36/2005 referring to Professor [Svante] Pääbo, and what stroke me was (quote): "Kleinste Defekte dieses Gens können ausreichen, un Artikulation und Sprachvermögen von Menschen erheblich zu beeinträchtigen." I may have to revise my own opinions on the issue of 'a language gene', an opinion that differs from that of, for instance, Noam Chomsky.

Og han svarede så at

[a]s for Svante Pääbo, he is certainly an impressive scholar, but I'm not sure that he'd be able to tell you much about mind, brain or language. His work on 'the language gene' is entirely based on members of a single family in Britain that exhibit a broad range of cognitive and other deficiencies (and he only knows about the genes - the work on the K2 family was done by others). My sense is that we are still very far from a serious understanding of the role of genes in cognition and especially language. Until recently, it seems that nobody had an inkling, but now some people think that they might have the beginning of a research programme. It also has a lot to do with the fact that genetics is one of the most popular and admired sciences these days. (Somewhat like linguistics in the late $19^{\text {th }}$ century, when biologists looked up to linguists.) Anyway, I think it would be very premature to think that Chomsky was proven right. (Martin Haspelmath, Max-Planck Institut für evolutionäre Anthropologie, Leipzig (personlig kommunikation)) 
Min model er således ikke svaret på hvorledes mentale og neurale processer hænger sammen, derimod er den svaret på den dybe teoretiske kløft der - igen ifølge Saeed (2003: 24) - findes imellem referens- og denotations-semantikken på den en side og repræsentations-semantikken på den anden side. Den første antager at semantik bedst beskrives ved hjælp af et begrebsapparat der identificerer de forbindelser der er mellem sproglige udtryk (ord og sætninger) og størrelser i resten af verden, og dette gøres ved at sige at sproglig betydning er det samme som sandhedsbetingelser. De klassiske indvendinger siges så at være relevante men uinteressante. Den anden antager at semantik er et spørgsmål om hvad der foregår i hovedet på folk i den forstand at såvel de sproglige udtryk som det sproglige indhold er repræsenteret i mentale eller kognitive processer, dvs. at koblingen mellem på den ene side sproglyd og skrift og på den anden side verden derude er mental eller kognitiv i sin natur. Historisk kommer den første før den anden og derfor er der endnu ikke klassiske indvendinger mod repræsentationssemantikken, men ligesom det første paradigme har mentalismemodellen sine basisproblemer. De to vigtigste er følgende: for det første ved vi ikke tilstrækkeligt om forbindelsen mellem mentale processer og neurale funktioner til at sige hvilke teorier om det mentale der er mest plausible (og teorier om relationer mellem specifikke sproglige fænomener og specifikke hjernefunktioner er endnu fjernere); for det andet medfølger der ikke nogen præciseringer af hvori forbindelserne mellem det mentale og de fysiske omgivelser (det jeg kalder det materielle) består. Referens-semantikkens alvorligste problem er det komplementære forhold at vi ikke ved hvad sandhed er når den skal bruges til at forklare betydning, og at vi ikke ved hvad betydning er når den skal bruges til at forklare sandhed. Mit eget svar er at sandhed kun er interessant hvis nogen lyver, eller, med andre ord, filosoffernes bekymringer eller mangel på samme ved sandhedsbetydningens Janus-hoved er lingvistisk uinteressante, for, som filosoffen Peter Gärdenfors siger i et arbejdspapir:

To put it tersely: Meaning comes before truth. (Gärdenfors 1990)

Et synspunkt jeg altså fuldt ud kan tilslutte mig. I det hele taget er min ambition at sammensætte en sprogteori der opløser såvel den ene som den anden semantiks svagheder, dvs. den indebærer at der i naturlige sprog findes en logik 
som ikke er sandhedsbaseret samt indebærer at det sproglige tegn antages at høre hjemme i et mentalt-konceptuelt system der, i form af perceptuelt bestemte udsnit, repræsenterer den materielle verden og processeres af neurale systemer. At vi stadig ikke ved hvori den sidstnævnte forbindelse består, er et problem som må udsættes til senere løsning, for jeg anser det for så uoverstigeligt vanskeligt at forklare hvori referens består hvis det ikke har noget at gøre med tankevirksomhed - eller at forklare hvorledes et udtryks domæne skulle være det samme som mængden af mulige anvendelser (specielt når ikke en levende sjæl ved hvad en mængde er) - at jeg finder det nødvendigt at antage en mental model for behandling af sproglige funktioner. Selv en filosof som i øvrigt ellers bevæger sig indenfor en denotationel/referentiel ramme og som er kendt for at have foreslået 'antirealisme' som epistemologi, føler det nødvendigt at fremhæve at:

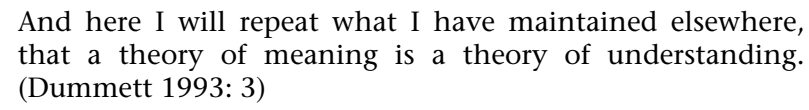

Også det kan jeg gå ind for, og inden for min model kan jeg så definere hvad en sætning er: nemlig formen i det minimale sproglige tegn, det sproglige tegn der ikke kan blive mindre hvis det skal kunne forstås, og jeg foreslår så en formal teori om syntaks (også kaldet $\operatorname{EFA}(\mathrm{X})$, jf. litteraturlisten) idet jeg antager at den syntaktiske grundstruktur er et simpelt system der er i stand til at generere de komplekse systemer som sprogbrugen viser sig at være. Jeg siger så at syntaksens grundlæggende størrelser er hvad vi traditionelt har kaldt sætningsled, men i stedet for substitutions- og distributionsprøver som kriterier for at identificere dem, foreslår jeg en definition der siger at et sætningsled er et udtryk for et begreb. Forudsætninger for og konsekvenser heraf vil føre vidt omkring, hvorfor jeg vil henvise til mine publikationer herom, men idéen er så at leddene skal vise hvem der er hvad, altså hvilke led der er hvilke led, for ellers kan logikken og informationen i sætningen ikke nå frem, og dette kalder jeg SYNTAKTISK SIGNIFIKATION (det sidste ord er valgt mest for ikke at få det blandet sammen med andre(s) ting). Denne kan så være enten TOPOLOGISK eller MORFOLOGISK, dvs. at det enten er udtrykkenes lineære formation der fortæller hvad der er fx subjekt og objekt, eller det er egenskaber ved morfemerne der fortæller det, i os nærtliggende sprog typisk gennem bl.a. kasusformer som nominativ og akkusativ. Inden for modellen kan jeg tillige definere hvad 
betydning er: det engelske ord 'meaning' vil jeg oversætte til betydning, og det befinder sig i det nederste lag af modellen på linie med indhold, pragmastruktur, information og stratifikation, og pragmatik er her noget lidt andet end ellers, nemlig det mentale univers som vi hver især bærer rundt på i hovedet og som primært er vores individuelle repræsentation af de ydre materielle omgivelser. Det mellemste lag kalder jeg så semantikken (med deraf følgende teoretiske termer), og jeg antager at der findes et mentalt system som kan kaldes et modul og som tager sig af de processer hvor bl.a. konventionaliserede forbindelser mellem udtryk og indhold opbevares, hvilket evt. kan kaldes et (mentalt) leksikon. Men bortset herfra og i samklang hermed findes der kun to typer af sproglige fænomener i det mentale system, nemlig udtryk og indhold (hvorved det her i den sidste ende kan komme til at ligne Saussures model). Et begreb er således defineret ved at være en forbindelse mellem ét udtryk og ét eller flere indhold eller mellem ét eller flere udtryk og ét indhold, og der findes ifølge mig altså ikke andre semantiske mekanismer end de nævnte forbindelser; en strukturel størrelse som jeg så analogt til syntaksen - og igen for at undgå forplumring af begreber - kalder SEMANTISK SIGNIFIKATION. Således er begreber i denne sammenhæng hverken noget der består af færdiglavede enkeltdele eller kan bygges op af semantiske primitiver. Og de er ej heller identiske med perceptuelt baserede forestillingsbilleder, ligesom de heller ikke har en mere eller mindre metafysisk status.

Begår jeg så ikke den videnskabelige helligbrøde at være cirkulær ved på den ene side at sige at et sætningsled er et udtryk for et begreb og på den anden sige at begreber ikke er andet en relationer mellem udtryk og indhold? Nej, det mener jeg ikke, og man kan evt. give påstanden en mere pædagogisk form ved at sige at et sætningsled er et begrebs udtryk, altså den ende af relationen som dels er et lydligt perceptuelt forestillingsbillede i det repræsentationelle system og dels de akustiske fænomener, og hvis anden ende af relationen er et begrebs indhold, dvs. mentale forestillingsbiller om et eller andet som blot ikke er udtryk. ${ }^{1}$ For mig er problemet ikke - således som det også behandles hos Saeed (2003: 32-46) - at det er næsten umuligt at finde ud af hvad begreber er for noget hvis de ikke er det samme som perceptuelle forestillingsbilleder (som det er tilfældet fx hos Jackendoff (jf. Jackendoff 2002)), problemet er snarere at begrunde udskillelsen af et særligt semantisk lag i modellen over det sproglige tegn hvis ellers semantik kun er klynger af relationer, men det lader for mig at se til at det er nødvendigt 
pga. klyngernes komplekse karakter, og derudover lader det til at realiserede kombinationer af udtryk og indhold kan lagres i hvad jeg og andre kalder for mentale leksikoner. Forholdet mellem realiserede sproglige tegn og nævnte lagring ville jeg - med en terminologisk begrundet korrigerende forandring af begrebet dialektisk - kalde *diataktisk, ${ }^{2}$ hvilket her betyder at forekomsten i et sprogligt tegn er en nødvendig forudsætning for lagring i et leksikon. Og ikke omvendt; dertil er jeg for meget empirist.

\section{DE SEMANTISKE ROLLER}

Når man kritiserer teorier eller deres dele så tager man altid udgangspunkt i sin egen mere eller mindre formulerede teoretiske verdensforståelse, og når jeg kritiserer en ubestemt rolle-teori så sker det også på baggrund af det teoretiske skelet som jeg har præsenteret ovenfor; og som kan udbygges med læsning i mine publikationer.

Den uforskammede indvending imod rollerne er at "jeg desværre aldrig har hilst på en tematisk rolle" og derfor må afskrive den slags som ikke eksisterende. Det vil selvfølgelig være at overtræde reglerne for både almindelighed høflighed og formal samt ikke-formal logik, for man kan ikke slutte fra det forhold at noget ikke er observeret til at det ikke findes - så derfor kunne jeg naturligvis aldrig finde på at sige sådan noget. Den næste indvending drejer sig om at rolle-teorien ikke har nogen plads i min teori, som selvfølgelig er den jeg er tilhænger af, men det kunne jo være et udtryk for min teoris mangelfuldhed. Man kunne i så fald spørge om den ville kunne få plads dér? Dertil må der godt nok svares nej. Der kan ikke med den bedste vilje findes noget sted hvor begreber som agenter, patienter og mål meningsfuldt ville kunne belyse struktureringen i eller af de pågældende mentale systemer. Og det har at gøre med det problem som jeg tog op i indledningen, nemlig spørgsmålet om hvor rolle-teorien kommer fra. Den er efter min opfattelse et forsøg på at forlige vores forståelse af at en sætnings betydning primært er et resultat af kombinationen af de ords betydninger som indgår i sætningen og det forhold at det ikke altid passer med hvad vi bruger sætninger til, altså den brede pragmatiks område. Det er en elementær erfaring inden for lingvistikken at vi som mennesker projicerer vores subjektive - eller subjektivt kollektive - antropomorfe forståelsesform ud i omgivelserne som fx halv- og heldøde metaforer som bordben og håndtag, som gletschere der kaelver eller som udvalg der nedkommer med en betoenkning. Vi har tilsyneladende også en 
tilbøjelighed til projicere subjektiv menneskelig handlen og tilsvarende narrativer ud i den ikke-narrative natur der ej heller besidder megen besjæling. Ikke-organiske ting som fx computere tillægges vilje: nå, vil du ikke! kan vi gribe os selv i at sige til den bærbare når den crasher. Og i en vis udstrækning har vi jo ret, for i sætninger der handler om mennesker har fx gavegivningen sin egen kasus eller linearitet:

\title{
(1) Peter giver Pia et aeble. \\ (2) Peter giver et aeble til Pia.
}

Pia er hvad jeg stadig i dansk vil kalde dativobjekt fordi dets syntaktiske signifikation enten er positionen foran objektet eller udtrykkes ved hjælp af præpositionen til, som jeg så dér vil kalde en adverbiel størrelse. I visse andre sprog vil dativobjektet have kasus dativ hvis det ikke er et proprium, og i atter andre vil det også have kasus dativ når det er et proprium. Så det ligger snublende nær at mene at der er en vis universalitet i bl.a. nævnte kasus. Men der har et stykke tid været en udveksling på diskussionslisten LINGTYP ${ }^{3}$ om netop sådanne forhold og Paul Hopper skriver 22. marts 2006 kl. 15:37:

\begin{abstract}
On Aashild's query about volitional patients: Some German verbs also take the dative when the human object is in some way complicit in the action. Examples would be schmeicheln 'flatter', gratulieren 'congratulate', folgen 'follow', begegnen 'meet'. But unlike Aashild's Icelandic example, the accusative is never an alternative.

Goethe notoriously wrote "Wer ruft mir?" "Who calls me?" (Faust I,1). 'Mich' in place of 'mir' (dat.) would be correct here, and Goethe is routinely accused of committing a solecism, but perhaps there is a subtle intention - the object being a spirit (Erdgeist) waiting to be summoned.
\end{abstract}

Kasus er åbenbart (og ud fra almindelig lingvistisk erfaring) ikke så let som man umiddelbart skulle tro, og tillige at tro at det altid afspejler en rollefordeling som i den ovenfor antydede kærlighedshistorie om Peter og Pia og æblet - vil ende med at blive kontraintuitivt, da virkeligheden jo er ret så prosaisk:

(3) Den økonomiske udvikling giver Danmark store muligheder.

(4) Lavtrykket giver Danmark regn over det meste af landet. 
På trods af at der i de senere år har bredt sig en litterær forståelsesform i store dele af vores kultur - hvilket bl.a. har medført at virksomhedskultur kan manifestere sig som 'fortællinger' - så er det for mig vanskeligt at opfatte økonomiske og meteorologiske beskrivelser som narrativer. Og det er hvad der ellers kunne begrunde forestillingen om at underliggende roller bestemmer nogle syntaktiske og morfologiske valg. Og det er måske lidt trist, for det teoretiske alternativ er ganske skræmmende. Det siger nemlig at de tematiske roller er de faktorer der bestemmer udformningen af de sproglige udtryk. Det ved vi fra det forhold at udvalget og fordelingen af tematiske roller stemmer overens med de udtryksmæssige kategorier, i traditionel forstand syntaks og morfologi. Og overensstemmelsen kan vi jo se ved at udtrykskategorierne passer ganske godt med de tematiske roller. Som jo er afspejlet i kategorierne i udtrykket. Vi kunne fortsætte længe endnu men man behøver ikke drive dette tilløb til parodi længere. Tankegangen ligner påfaldende hvad en britisk kollega ville kalde 'vicious circularity', dvs. at tematiske roller og udtrykskategorier blot er forskellige betegnelser for det samme, hvilket gøres så meget lettere af at lingvister sjældent er enige om hvilke udtrykskategorier og hvilke tematiske roller der faktisk findes - hvis man ellers kan bruge lige de ord om det.

Hvilket fører mig til de filosofiske indvendinger mod rolle-teorien. Den første er epistemologisk. Det vil være ganske svært at opstille kriterierne for en evt. verifikation af hypoteser der er afledt af en teori om tematiske roller. Antager vi at vi skal bruge et rolle-begreb indenfor referens- og denotations-teorien må vi spørge hvilke funktioner rollerne ville kunne supplere eller overtage. I selv en primitiv subjekt/prædikat-logik kan rollerne ikke få nogen plads i propositionseller argumentationsfunktionerne, og det samme gælder prædikatslogik; selvom nogen påstår noget der ligner, jf. nedenfor. Og de vil heller ikke kunne svare på hvori den imaginære snor består som referensbegrebet lettere metafysisk antager der er mellem udtryk og entitet, ligesom de ej heller vil kunne sige noget relevant om sandhed og betydning som komplementære og intuitive begreber. Antager vi alternativt at vi skal bruge et rolle-begreb indenfor repræsentationsteorien, så kan vi kun vanskeligt svare på hvor og hvordan roller skulle kunne identificeres i de mentale systemer. Kun i min egen model kan man sige at den mentale repræsentation af andre menneskers adfærd i det enkelte individ ligner roller, men netop denne repræsentation er jo ikke en slags kantiansk erkendelsesmåde - således at rollerne skulle være kategorier for 
erkendelsen - for repræsentationerne er netop den eneste erkendelsesform vi har, hvorfor rollerne ikke både kan være en del af erkendelsesformen og samtidig en erkendelsesmåde der anvendes på erkendelsesformen. Det ville være en selvmodsigelse, og tankeforløbet ville være næsten analogt med de engelske empiristers velkendte århundredlange refleksioner over erkendelsens egentlige genstande, et forløb der bl.a. ustrakte sig fra Locke over Berkeley til Hume og tillige strækker sine begrebslige fangarme helt op til vor tid (jf. Skorupski 1993). Der er altså - efter min opfattelse - ikke nogen af disse teoribygninger der kan inkorporere tematiske roller således at der kan formuleres hypoteser om analyse af sproglige udtryk, fx sætninger, således at det videre kan begrundes at tematiske roller har en funktion i fx sætningsstrukturen, og dermed vise at teorien kan verificeres eller er blot adækvat. Dermed ikke være sagt at folk indenfor teorierne, fx Jackendoff, ikke gør sådan noget. Men det fører mig blot til varianten af påviselighedsproblemerne: det vil være næsten umuligt at opstille falcifikationskriterierne for hypoteser der er afledt af en teori om tematiske roller. Eller sagt på en anden måde: der er næppe nogen analyse eller noget teoretisk fremskridt der vil kunne godtgøre at der ikke findes tematiske roller. Dels kan de cirkulært erstatte udtrykskategorierne i analysen, og dels har vi - qua deres egen teoridannelses uklarheder - ikke nogen ontologiske kategorier som vi kan henføre dem til, hvorfor vi for hver enkelt ontologisk kategori ikke kan vide om de ikke tilhører kategorien. Karl Popper (jf. Popper 1934, evt. Popper 1989) ville så have sagt at de ikke var udtryk for en videnskabelig teori, men da vi endnu ikke har nogen højesteret for hvad der er videnskab må vi lade det stå for hans egen regning. Også for ikke at blive uvenner med nogen.

Hvorfor har vi dem så, de tematiske roller? Hvilket er et andet spørgsmål end hvor de kommer fra, jf. ovenfor, og hvilket fører til en ontologisk indvending. I mit verdensbillede er de således et eksempel på hvad Arne Thing Mortensen kalder 'den ontologiske fejltagelse':

[...] en sammenkædning af beskrivelse og eksistens på en sådan måde, at beskrivelsen projiceres ind i den beskrevne ting som noget, der findes - eksisterer - $\mathrm{i}$ tingen. (Mortensen 1971: 59) 
Troen på at fordi vi har et ord for noget så eksisterer det også som selvstændig entitet, lidt ligesom hvad nogle kalder en hypostasering. I dette tilfælde således at rolle-beskrivelsen projiceres ind i sproget. Men - atter i mit verdensbillede - så har vi i den sidste ende ikke andet, så at sige, at hænge vores forståelse op på end udtrykkene og det indhold som er mentale repræsentationer af tingene i den verden som vi er omgivet af og som vi handler i. Der er ikke noget derimellem bortset fra den hjerne som bearbejder begge dele. Vi kan godt bruge hjernens muligheder til fx at abstrahere fra det konkrete indhold og fx danne udtryksformer som kun har en kringlet vej til de anskuelige omgivelser. Det gør vi når $\mathrm{fx}$ talord bliver manipuleret som symboler $\mathrm{i}$ form af hvad vi kalder arabertal, og det kan raffineres til symbolismer og formale systemer i fx algebra, som er en udfordring for tanken, eller anvendt matematik, som er uhyre praktisk. Men hjernens muligheder for abstraktion kan også få os til at fortabe os i problemer som fx spørgsmålet om betydningen af ordet trekant, talordet ét (dvs. modsvarende talsymbolet 1) eller det matematiske ord moengde (jf. Dummett 1991), et problem som kan føre til frugtbare filosofiske overvejelser men næppe til noget der belyser lingvistisk semantiske teorier, og at prøve at finde semantikkens inderste kerne er formodentlig lige så håbløst som at prøve at løse gåden om det menneskelige, subjektive identitetsproblem. Hvilket ikke udelukker eksistensen af hverken Gud eller menneskesjæle. Det spørgsmål ligger blot uden for mulig viden.

En konsekvens af dette mit synspunkt er at jeg altid - i mit professionelle liv med sprogvidenskaben - har fundet det ubegribeligt at nogen kunne slippe af sted med noget som det her:

\begin{abstract}
Semantic functional relations are one of the two major types of relation between a predicate and its argument(s); the other type is syntactic relations (see Sect. 3). They are important for a variety of reasons. They are empirically important because they capture the basic structure of events. [...] a way of talking about who did what to whom. [...] There should be some relationship between the structure of the event and the linguistic encoding of it. [...] 'agent' argument [...] 'patient' argument [...] (van Valin Jr. 1999: 150; min fremhævelse)
\end{abstract}

Overfladisk set kunne det se ud som en udvandet udgave af den filosofisk-logiske korrespondensteori (indenfor denotations-/referensteorien) om sandhedsværdier - i hvilken man derved med nogle få ord i en bisætning overflødiggør et par 
tusind års filosofisk diskussion om forholdet mellem sproglig betydning og virkeligheden - men da det her drejer sig om sproglige funktioner beskrevet af lingvistiske teorier så er der her nærmere tale om et overdimensioneret anfald af en variant af den ontologiske fejlslutning. Dels må man spørge om det begrundet kan hævdes at der findes nogen 'begivenhedernes grundstruktur', dels må man spørge hvad i menneskers forståelsesformer der gør at de kan antages at kode bemeldte grundstruktur efter universelle principper i forskellige sprog. Blot i et morfologisk primitivt sprog som dansk har vi to standardmåder at kode en 'give-handling' på, jf. fortællingen om Peter og Pia og æblet ovenfor, og inddrager vi metaforiske udtryksformer øges variationen overvældende. Men det er de altså, universelle:

They must be universal, because if a language is going to function, to convey information, it needs to have ways of coding these kinds of relations. (Ibid.)

Jeg er enig i at sprog må kunne flytte information, men det kan det også sagtens gennem kombinationer af leksikalske og morfologiske betydninger uden at der behøver at findes nogen 'semantiske roller' i det indre scenaries conceptualisering af begivenheder i verden eller i bestemte sprogformers mekaniske tilknytning til dele af et sådan scenarie.

Et relevant spørgsmål til denne teoretiske afgrænsning af problemet om hvad sprog er, vil være om ikke der skal være plads til en mental konceptualiseringsmekanisme som kan bruges til at kende og genkende størrelser i den omgivende fysiske virkelighed (et svar på hvad Dummett kalder 'forståelse'). Jo, som tentativt teoretisk stillads vil jeg foreslå at man opererer med en forestilling om individet som et personligt handlende subjekt og at den enkeltes (repræsentationelle) oplevelsesverden er orienteret i et hvad nogen kalder et deiktisk centrum. Sådan et fungerer så som en form for mentalt koordinatsystem med repræsentationer af både spatiale og temporale dimensioner, og lige for tiden vil jeg kalde systemet for en mental matrice (engelsk matrix, idet termen ganske vist er optaget til andre ting men altså ikke lige til det), men det er muligt at jeg finder på noget andet. En mental matrice vil jeg så definere som en (i min forstand, jf. tegnbegrebet) en mængde (sic!) af konfigurationer der repræsenterer situationer og objekter fra den fysiske omverden der er erfarede eller evt. udtænkte (dvs. fiktive) og som opbevares i det 
jeg kalder niveauet af stratifikation af perceptuelt baserede forestillingsbilleder, som endelig kan være af større eller mindre abstraktionsgrad. Forestiller man sig videre at matricen løbende instantieres - i hvert fald når vi er vågne - så er det matricens aktuelle indhold vi taler om når vi snakker, for vi kan jo ikke tale om andet da matricen er vores eneste adgangsvej til virkeligheden, og så er sprogets almindelige gloser vældigt praktiske, fx deiktiske pronominer om mig og dig og vi to, ligesom bestemthed kan være ganske praktisk men selvsagt kan undværes. Men, og det skal understreges, deraf følger ikke at matricen er en slags naturalistisk teater hvor 'agenter' og 'patienter' udgør en del af rollebesætningen. Matricen repræsenterer mentalt hvad vi på filosofisk vis må nøjes med at kalde entiteter og hvad der måtte være imellem dem - hvis der overhovedet kan være noget derimellem. Der er med andre ord ingen tematiske roller der sniger sig ind ad bagvejen fordi jeg er nødt at medgive at der må findes et mentalt apparatur til konceptualisering af virkeligheden og dens situationer, og skulle jeg en dag kunne udvikle disse strøtanker til en egentlig teori så kan jeg ikke forestille mig at rollerne vil dukke op igen.

\section{EN PADAGOGISK SAMMENFATNING}

Som jeg ser det findes der altså ikke noget man kunne kalde tematiske roller i de mentale systemer som må antages at processere sproglige funktioner, og med min sprogopfattelse er det næppe heller ikke et begreb som jeg ville anvende $i$ forbindelse med hverken teoretisk eller anvendelsesorienteret undervisning i og om sprog. På den ene side er sprog de af mig nævnte sproglige funktioner, og jeg mener at de bedst beskrives ved hjælp af formale teorier og modeller; på den anden side er sprog den brug mennesker gør af det til kommunikation og kognition, og jeg mener at det sidste bør veje tungt i udvælgelsen af de grundforudsætninger som en sprogteori opstilles på; det nogle ville kalde en universalpragmatik. Dermed forliger man hvad jeg ville kalde pseudodichotomien "Formalister overfor Funktionalister", og der tilbydes et apparat til såvel formalisering som deskriptivt opsøgende arbejde, en modsætning som ellers kun kan vedligeholdes som sådan af ekstremister og som i virkeligheden er et komplementært forhold - de forudsætter nødvendigvis hinanden. Det er sprogvidenskabeligt lige så vigtigt at granske runeindskrifter som at lave endnu en grenstruktur over en isoleret sætning i et eksotisk sprog. Blot har tematiske roller ikke noget at gøre i nogen af delene. 


\section{LITTERATUR}

Dummett, Michael (1991), Frege. Philosophy of Mathematics, London: Duckworth.

Dummett, Michael (1993), The Seas of Language, Oxford: Clarendon Press.

Gärdenfors, Peter (1990), "The Emergence of Meaning", working paper, Cognitive Science, Department of Philosophy, Lund University.

Götzsche, Hans (2005a on-line publication), "An Introduction to Formative Grammar: The Theory of Epi-Formal Analysis in $\operatorname{Syntax}(\operatorname{EFA}(\mathrm{X}) 2)$ " [http://www.cfl.hum.aau.dk/linguistics/index.html]

Götzsche, Hans (2005b on-line publication), "What is movement in Formative Grammar (EpiFormal Analysis in Syntax (EFA(X)2)" [http://www.cfl.hum.aau.dk/linguistics/index.html]

Götzsche, Hans (2005c on-line publication), "EFA(X)2: Definitions and formalisms"

[http://www.cfl.hum.aau.dk/linguistics/index.html]

Jackendoff, Ray (2002), Foundations of Language, Oxford: Oxford University Press.

Mortensen, A. Thing (1972), Perception og sprog. Et filosofisk essay, København: Akademisk Forlag.

Popper, Karl (1934 (1969)), Logik der Forschung, Tübingen: J. C. B. Mohr (Paul Siebeck).

Popper, Karl (1989; $5^{\text {th }}$ Ed., repr. 1991), Conjectures and Refutations. The Growth of Scientific Knowledge, London: Routledge.

Saeed, John I. (2003; $2^{\text {nd }}$ Ed.), Semantics, Oxford: Blackwell Publishing.

Saussure, Ferdinand de (1916), Cours de Linguistique Generale, Paris: Payot.

Skorupski, John (1993), English-language Philosophy 1750-1945, Oxford, New York: Oxford University Press.

Valin Jr., R. D. van (1999), "Functional Relations", in: Brown, Keith, Jim Miller (eds.) (1999), Concise Encyclopedia of Grammatical Categories, Amsterdam, New York: Elsevier, pp. 150-162.

\section{NOTER}

1 Jeg skal ikke lige her blande mig i den årtusinder gamle diskussion om virkelighedens og begrebers ontologiske status: idealisme, rationalisme, empirisme, pragmatisme, begrebsrealisme etc.

2 Græsk leksis 'ord' associerer snarere til noget med tale og samtale mens græsk taksis 'orden' bedre dækker noget med struktur uanset af hvilken natur den er.

3 lingtyp@listserv.linguislist.org 